\title{
DETERMINATION OF LEAD AND CADMIUM IN THE WATER OF THE DAMAVAND RIVER, IRAN
}

\author{
KHORAMNEJADIAN, S. ${ }^{*}$ - FATEMI, F. \\ Department of Environment, Damavand Branch, Islamic Azad University, Damavand, Iran \\ *Corresponding author \\ e-mail: khoramnejad@damavandiau.ac.ir; phone:+989357970978
}

(Received $15^{\text {th }}$ Sep 2016; accepted $15^{\text {th }}$ Dec 2016)

\begin{abstract}
Heavy metals contamination of surface waters has become an important issue in the last decades. The present study aimed to investigate the levels of lead and cadmium in the water of the Damavand River, Iran. Sampling was carried out in 10 stations during summer and autumn 2015. Metal analysis was performed by atomic absorption spectrophotometer. Surface water at each sampling point was measured for selected physicochemical parameters with a multiparameter meter. Statistical analysis was carried out by SPSS and Excel software. The results showed that the mean concentrations $(\mathrm{mg} / \mathrm{L})$ of lead in the samples were higher than cadmium over the studied months. The highest levels of lead $(2.13 \pm 0.80)$ and cadmium $(1.03 \pm 0.50)$ were found in station 9 while the lowest levels of lead $(0.09 \pm 0.00)$ and cadmium $(0.03 \pm 0.00)$ were in station 1 (before entering the city of Damavand). Significant differences $(\mathrm{P}<0.05)$ were observed between the stations, however, there were no significant variations between the levels of metals in the months. Significant differences were found between the levels of physicochemical parameters among different months at 95\% confidence level. Present values revealed that the concentrations of metals in the stations were higher than the maximum permitted levels for drinking water set by different organizations.
\end{abstract}

Keywords: anthropogenic activities, heavy metals, river pollution, surface waters, water quality

\section{Introduction}

The pollution of surface water ecosystems as a result of anthropogenic and natural sources has become a growing global concern (Aktar et al., 2010). Over the past half century, human activities have altered the natural balance of aquatic environment. This can lead to destroy the natural environment and natural resources of future generations (Salati and Moore, 2009). The contamination of surface waters by heavy metals is one of the most serious environmental problems due to their bioaccumulation capabilities (Diagomanolin et al., 2004). In order to develop and implement an effective environmental management, knowledge of the changing levels of heavy metals and their possible source in the environment is necessary (Owamah, 2013).

Heavy metals are found in natural aquatic systems in low levels; however, the excess load of these metals in water bodies as a result of anthropogenic inputs could be a great concern (Abubakar et al., 2015). Although some metals like iron and zinc are needed as micronutrients for plants and animals in low levels, other metals like cadmium (Cd) and lead $(\mathrm{Pb})$ are known to be extremely toxic to living organisms even at low concentrations (Kar et al., 2008). Industrial activities and discharges of untreated effluents, waste and agricultural runoff are the major human sources of heavy metals pollution (Varol and Sen, 2012). Heavy metals can accumulate in aquatic organisms, persist in water and find their way to human body through drinking water or via the food chain (Reyhani et al., 2013; Varol and Sen, 2012). The levels of metals in aquatic environment are generally monitored by determining their levels in water, sediment and biota (Alex et al., 2013). 
Water quality in urban river systems is under increasing stress because of industrial and domestic wastewater effluents and agricultural runoff (Al Obaidy et al., 2014). Many rural citizens throughout the world tend to use river water for household needs and thus anthropogenic activities have threatened their water supply (Sibanda et al., 2014). The River Damavand running by the side of the Damavand City in Iran, receives municipal and industrial loads from its surrounding environment. Many industrial units have set up in the downstream of the river and the number of industries in this area is continuously increasing. This river plays an important role in supplying water for municipal and agricultural uses, and thus there is an urgent need to measure and monitor metals of the river.

Some studies in the literature have focused on heavy metal pollution of water resources in Iran (Salati and Moore, 2010; Diagomanolin et al., 2004); however, no studies have been conducted examining the levels of metals in the Damavand River. Cd and $\mathrm{Pb}$ are among the most important pollutants in the study area, as a result of surface runoff discharges of industries like steel and cement factories. The objective of this study was, therefore, to determine the concentration of $\mathrm{Pb}$ and $\mathrm{Cd}$ in the water of Damavand River and to compare the results with the acceptable metal limits given by international organizations.

\section{Materials and Methods}

The Damavand River situated between $35^{\circ} 70^{\prime} 13^{\prime \prime} \mathrm{N}$ and $52^{\circ} 05^{\prime} 86^{\prime \prime} \mathrm{E}$ and originates from the Damavand Mountains in the northeast of Tehran province in Iran. There are various industries like electroplating, chemicals, wood preservations, iron and steel, cement, plastic and rubber industries which are in an industrial area, located in downstream of the river (Khoramdasht region). There are also villages, and agricultural lands built on both sides of the river. The river is used by the local residents for various activities such as swimming and drinking.

Water samples were collected once monthly from July to December 2015. Samples were chosen from 10 sampling stations along the Damavand River (Table 1) at a depth of approximately $20 \mathrm{~cm}$ below the surface, poured into sterilized bottles, kept in an ice pack and transported to the laboratory for analysis. No sample was collected at station 9 in September and October due to very low flow at this site. On each sampling station, selected water physicochemical parameters (temperature, $\mathrm{pH}$ and electrical conductivity) were monitored using a multiparameter meter from Hach (model senION156). The levels of $\mathrm{Cd}$ and $\mathrm{Pb}$ in the water samples were determined using method 3111 of the standard methods for the examination of water and wastewater by Air-acetylene flame atomic absorption spectrophotometry (APHA et al. 1998).

The analytical data quality was guaranteed through accomplishment of laboratory quality assurance and quality control methods, including calibration with standards, use of standard operating procedures and analysis of both reagent blanks and replicates. Statistical analysis was performed using SPSS v.22 and Excel 2010 software. The analysis of variance (ANOVA) followed by Duncan test $(\alpha=0.05)$ was applied to determine the differences among the groups. 


\section{Results}

The geographical characteristics of the sampling stations and the concentrations of $\mathrm{Pb}$ and $\mathrm{Cd}$ in water samples from different stations are presented in Table 1. Analysis of variance revealed significant differences $(P<0.05)$ in $\mathrm{Cd}$ and $\mathrm{Pb}$ levels between sampling stations. The abundance of $\mathrm{Pb}$ and $\mathrm{Cd}$ in the stations followed the order: $\mathrm{S} 1<\mathrm{S} 2=\mathrm{S} 3=\mathrm{S} 4<\mathrm{S} 5=\mathrm{S} 6<\mathrm{S} 7=\mathrm{S} 8=\mathrm{S} 10<\mathrm{S} 9$ and $\mathrm{S} 1<\mathrm{S} 2=\mathrm{S} 3=\mathrm{S} 4<\mathrm{S} 5=\mathrm{S} 6=\mathrm{S} 7<\mathrm{S} 8=\mathrm{S} 10<\mathrm{S} 9$, respectively, according to Duncan test. Temperature, $\mathrm{pH}$, and electrical conductivity levels of the Damavand River surface water during sampling months are given in Table 2. The Duncan test revealed that there was a significant variation between the levels of these three physicochemical parameters among different months at $95 \%$ confidence level. Fig 1. provides information about monthly variations of $\mathrm{Cd}$ and $\mathrm{Pb}$ concentrations in the samples during six-month sampling period. Levels of both metals fluctuated slightly, but the trends were downward. The results from the present study were also compared with standards established by different organizations.

Table 1. Geographic locations of the stations and mean levels (Mean \pm SD) of heavy metals in the stations during sampling months

\begin{tabular}{c|c|c|c|c}
\hline Stations & Location & $\begin{array}{c}\text { Altitude above } \\
\text { sea level }\end{array}$ & $\begin{array}{c}\text { Pb } \\
\text { (mg/lit) }\end{array}$ & $\begin{array}{c}\text { Cd } \\
(\mathbf{m g} / \mathbf{l i t})\end{array}$ \\
\hline 1 & $\begin{array}{c}\text { Rouh-afza region (Before } \\
\text { entering the city of Damavand) } \\
\text { Entrance to the city of } \\
\text { Damavand }\end{array}$ & 2033 & $0.09 \pm 0.00$ & $0.03 \pm 0.00$ \\
3 & Farameh region & 1994 & $0.10 \pm 0.00$ & $0.04 \pm 0.02$ \\
4 & Valiran region & 1924 & $0.10 \pm 0.01$ & $0.04 \pm 0.02$ \\
5 & Under the Shalambeh Bridge & 1826 & $0.13 \pm 0.04$ & $0.05 \pm 0.02$ \\
6 & Hesar paein region & 1786 & $0.21 \pm 0.14$ & $0.18 \pm 0.12$ \\
7 & Mara region & 1735 & $0.67 \pm 0.35$ & $0.24 \pm 0.19$ \\
8 & Khoramdasht region & 1695 & $1.17 \pm 0.65$ & $0.65 \pm 0.36$ \\
9 & Zaredareh region & 1421 & $2.13 \pm 0.80$ & $1.03 \pm 0.50$ \\
10 & Entrance to the Mamlo Dam & 1309 & $1.52 \pm 0.93$ & $0.78 \pm 0.47$ \\
\hline
\end{tabular}

Table 2. The mean and standard deviations of physicochemical parameters of water in the studied stations during the 6-months studied period

\begin{tabular}{c|c|c|c|c|c|c}
\hline \multirow{2}{*}{ Parameters } & \multicolumn{5}{|c}{ Months } \\
\cline { 2 - 6 } & July & August & September & October & November & December \\
$\begin{array}{c}\text { Temperature } \\
\left({ }^{\circ} \mathrm{C}\right)\end{array}$ & $22.82 \pm 0.55$ & $24.89 \pm 0.51$ & $24.64 \pm 0.33$ & $14.47 \pm 8.54$ & $6.27 \pm 0.19$ & $6.07 \pm 0.35$ \\
$\mathrm{pH}$ & $7.65 \pm 0.34$ & $7.46 \pm 0.32$ & $7.95 \pm 0.25$ & $7.72 \pm 0.30$ & $7.70 \pm 0.11$ & $7.69 \pm 0.17$ \\
$\begin{array}{c}\text { Electrical } \\
\text { conductivity } \\
(\mu \mathrm{mhos} / \mathrm{cm})\end{array}$ & $764.30 \pm 80.70$ & $826.33 \pm 11.88$ & $805.78 \pm 104.87$ & $701.56 \pm 96.60$ & $730.00 \pm 65.78$ & $791.40 \pm 187.63$ \\
\hline
\end{tabular}




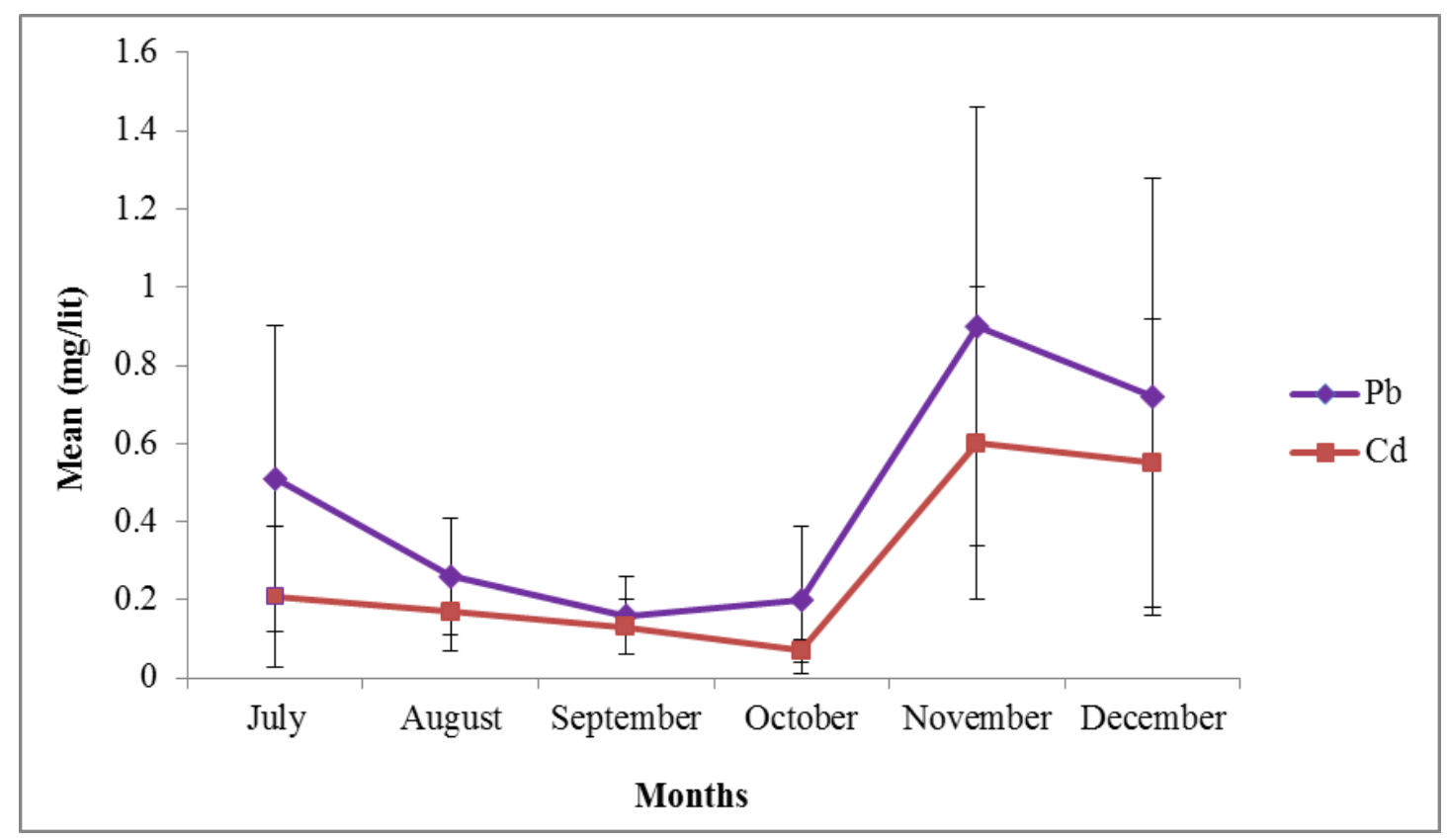

Figure 1. Monthly variation in mean levels of heavy metals ( $\mathrm{mg} / \mathrm{lit}$ ) in the studied months

\section{Discussion}

Regarding Table 1, station 1 showed significantly lowest levels of $\mathrm{Pb}(0.09 \pm 0.00)$ and $\mathrm{Cd}(0.03 \pm 0.00)$ in water samples at $95 \%$ confidence level while station 9 had significantly highest levels of $\mathrm{Pb}(2.13 \pm 0.80)$ and $\mathrm{Cd}(1.03 \pm 0.50)$. An obvious explanation for this result is that the Damavand River at upstream points receives lower amounts of wastewater effluents, due to location of the industrial unit in the downstream part of the river. An earlier study on Tigris River, Turkey also reported that heavy metal concentrations in water samples at sites situated downstream of the copper mine plant were higher than the other sites (Varol and Sen, 2012). A decrease in metal levels at station 10 is probably due to a dilution process. The nonsignificant differences between levels of $\mathrm{Cd}$ and $\mathrm{Pb}$ in some stations indicate that these metals originate from the same source of pollution. The concentrations of heavy metals in this study were higher than those reported by Salati and Moore (2010) in the Khoshk River at Shiraz, Iran and those found in Sava River in Serbia (Vukovic et al., 2011).

The comparison of metal levels in the presents study with international standards revealed that $\mathrm{Cd}$ and $\mathrm{Pb}$ concentrations in water samples from all the stations were above standard values of $0.003 \mathrm{mg} / \mathrm{lit} \mathrm{Cd}$ and $0.01 \mathrm{~Pb} \mathrm{mg} / \mathrm{lit}$ in drinking water set by World Health Organization (WHO) and $0.005 \mathrm{mg} / \mathrm{lit} \mathrm{Cd}$ and $0.015 \mathrm{~Pb} \mathrm{mg} / \mathrm{lit}$ suggested by Environmental Protection Agency (EPA) (WHO 2008; USEPA, 2009). The same condition was reported by Owamah (2013) in a petroleum impacted river in the Niger Delta region. In a study from Sardabrud River in north of Iran, the levels of $\mathrm{Pb}$ and $\mathrm{Cd}$ were recorded lower than the maximum permitted concentration for drinking water quality set by WHO and EPA (Reyhani et al., 2013).

According to Table 2, there was a marked decrease in water temperature (from $24.89 \pm 0.51^{\circ} \mathrm{C}$ to $6.07 \pm 0.35{ }^{\circ} \mathrm{C}$ ) from August to December. The mean levels of temperature across the sampling months followed the order: August $=$ September $=$ July $>$ October $>$ November=December in accordance with Duncan test results. Generally, 
warmer water temperatures in aquatic ecosystems (more than $25{ }^{\circ} \mathrm{C}$ ) may affect the toxicity of some chemicals in the water (Sibanda et al., 2014); however, the temperature range in this study was lower than $25^{\circ} \mathrm{C}$. Significantly $(\mathrm{P}<0.05)$ lower mean level of $\mathrm{pH}$ $(7.46 \pm 0.32)$ was recorded in August while significantly $(\mathrm{P}<0.05)$ higher levels $(7.95 \pm 0.25)$ were observed in September. $\mathrm{pH}$ values in this study were within the permissible $\mathrm{pH}$ ranges for drinking water recommended by WHO (WHO, 2008). A study on river waters in western Tamil Nadu, India indicated that $\mathrm{pH}$ levels of the waters were within the acceptable ranges for aquatic life (Rajiv et al., 2012). Data also shows a significant $(\mathrm{P}<0.05)$ lower level of electrical conductivity $(701.56 \pm 96.60)$ in October and significant $(\mathrm{P}<0.05)$ higher mean level of this parameter $(826.33 \pm 11.88)$ in August. The levels of electrical conductivity in this research were higher than that in Densu River of Ghana (Karikari and Ansa-Asare, 2006).

As we can see in this graph, the mean concentrations (mg/lit) of $\mathrm{Pb}$ in the samples were higher than $\mathrm{Cd}$ over the studied months. The highest mean levels of $\mathrm{Pb}$ $(0.90 \pm 0.56)$ and $\mathrm{Cd}(0.60 \pm 0.40)$ were found in November. The lowest values of $\mathrm{Pb}$ $(0.16 \pm 0.10)$ were recorded in September while lowest levels of $\mathrm{Cd}(0.07 \pm 0.03)$ were in October; however, ANOVA showed that there were no significant variations between the levels of both metals in the months at $95 \%$ confidence level. This result could be explained by the fact that there was heavy rainfall in both summer and autumn seasons in the study area that resulted in distribution of metals within the river water .In a previous research study on evaluating heavy metals in Karoon River, Iran levels of heavy metals in water samples were reported higher during rainy months (Diagomanolin et al., 2004). A report from Ganga River in India showed significant seasonal changes in the levels of $\mathrm{Cd}$ and nonsignificant changes in the concentration of $\mathrm{Pb}$ during the studied period (Kar et al., 2008).

In conclusion, Damavand River has been seriously polluted by heavy metals due to industrial and municipal activities in the surrounding area. High levels of heavy metals $(\mathrm{Pb}, \mathrm{Cd})$ in water samples compared to $\mathrm{WHO}$ and EPA guidelines for water quality signifies potential health risks to consumers. Untreated discharges of urban sewage and industrial wastes are the main causes of poor water quality in this region. To reduce the existing quantity of metal contamination in the Damavand River, solid and liquid waste management practices are highly required.

Acknowledgments This research is supported by the research and technology fund of Damavand Branch, Islamic Azad University, Damavand, Iran.

\section{REFERENCES}

[1] Abubakar, A. J., Yusuf, S., Shehu, K. (2015): Heavy metals pollution on surface water sources in Kaduna metropolis, Nigeria. - Science World Journal 10: 1-5.

[2] Aktar, M. D. W., Paramasivam, M., Ganguly, M., Purkait, S., Sengupta, D. (2010): Assessment and occurrence of various heavy metals in surface water of Ganga River around Kolkata: a study for toxicity and ecological impact. - Environmental Monitoring and Assessment 160:207-213.

[3] Alex, E., Lawrence, E., Frances, A. (2013): Heavy metal concentrations in surface water and bioaccumulation in fish (clarias gariepinus) of River Owan, Edo State, Nigeria. European International Journal of Science and Technology 2:31-39. 
[4] Al Obaidy, A. H. M. J., Al Mashhady, A., Awad, E. S., Kadhem, A. J. (2014): Heavy metals pollution in surface water of Mahrut River, Diyala, Iraq. - International Journal of Advanced Research 2:1039-1044.

[5] APHA, AWWA, WEF. (1998): Standard methods for the examination of water and wastewater. - Washington, DC., APHA-AWWA-WEF.

[6] Diagomanolin, V., Farhang, M., Ghazi-Khansari, M., Jafarzadeh, N. (2004): Heavy metals $(\mathrm{Ni}, \mathrm{Cr}, \mathrm{Cu})$ in the Karoon waterway river, Iran. - Toxicology Letters 151:63-68.

[7] Kar, D., Sur, P., Mandal, S.K., Saha, T., Kole, R.K. (2008): Assessment of heavy metal pollution in surface water. - International Journal of Environmental Sciences and Technology 5:119-124.

[8] Karikari, A.Y., Ansa-Asare, O.D. (2006): Physico-chemical and microbial water quality assessment of Densu River of Ghana. - West African Journal of Applied Ecology 10: 87100.

[9] Owamah, H. I. (2013): Heavy metals determination and assessment in a petroleum impacted river in the Niger Delta Region of Nigeria, - Journal of Petroleum and Environmental Biotechnolgy 4: 1-4.

[10] Rajiv, P., Salam, H. A., Kamaraj, M., Rajeshwari, S., Sankar, A. (2012): Physico chemical and microbial analysis of different river waters in western Tamil Nadu, India. I Research Journal of Environment Sciences 1(1): 2-6.

[11] Reyhani, P., Ansari, M.R., Saeb, K. (2013): Assessment of heavy metals contamination in surface water of the upstream Sardabrud River, North of Iran. - Life Science Journal 10: 884-892.

[12] Salati, S., Moore, F. (2010): Assessment of heavy metal concentration in the Khoshk River water and sediment, Shiraz, Southwest Iran. - Environmental Monitoring and Assessment 164: 677-689.

[13] Sibanda, T., Chigor, V. N., Koba, S., Obi, C.L., Okoh, A.I. (2014): Characterisation of the physicochemical qualities of a typical rural-based river: ecological and public health implications. - International Journal of Environmental Science and Technology 11:17711780.

[14] USEPA. (2009): National Primary Drinking Water Regulations- United States Environmental Protection Agency. EPA 816-F-09-004.

[15] Varol, M., Sen, B. (2012): Assessment of nutrient and heavy metal contamination in surface water and sediments of the upper Tigris River, Turkey. - CATENA 92: 1-10.

[16] Vukovic, Z., Markovic, L., Radenkovic, M., Vukovic, D., Stankovic, S. (2011): Heavy metal and bacterial pollution of the Sava River in Serbia. - Arh Hig Rada Toksikol 62: 11-16.

[17] WHO. (2008): Guidelines to drinking water quality. -World Health Organization. Geneva, Switzerland. 